\title{
Global, regional, and national burden of dementia, 1990-2016
}

\section{Predictions need local calibration}

Maria Stylianou Korsnes, PhD, and Andrea Sylvia Winkler, MD, Drmed, PhD

Neurolog ${ }^{\circledR}$ 2020;94:718-719. doi:10.1212/WNL.0000000000009301

Dementia is 1 of the 5 major global causes of death. ${ }^{1}$ In 2015/2016, an estimated $43-47$ million people were living with dementia disease, expected to increase to over 100 million by $2050{ }^{1}$ The largest increase is anticipated in low- and middle-income countries. ${ }^{1}$ To give policy makers a tool to delay the onset of dementia, it is pertinent to map the contributing risk factors nationally. Studies report up to $35 \%$ of dementia burden to be due to known, potentially modifiable risk factors: hearing loss, low education, midlife hypertension, smoking, depression, physical inactivity, social isolation, diabetes, and midlife obesity. ${ }^{2}$ A report from the Global Burden of Diseases, Injuries, and Risk Factors Study 2016 Dementia Collaborators ${ }^{1}$ attempts to provide such a tool for further research and national public health decisions. However, the authors state that their data are tainted by several major limitations relating to considerable heterogeneity in diagnostic procedures, inconsistencies in registration of dementia as cause of death, and assumption of transferability of findings between countries with different health care systems.

The authors had to overcome multiple challenges relating to discrepancies in data in order to create prediction models. The challenges included within-country death rate estimates with 50 times variation between the highest and lowest estimate in different locations and Mini-Mental State Examination scores, where the cutoff score varied from 18/30 to 28/30. Comparing data from 1990, 2006, and 2016 also presented challenges given the development of new diagnostics protocols during this time period modulated with 230 different diagnostic procedures used in 237 available data sources. Critics ${ }^{3}$ have noted that mortality data from 4 predominately highincome locations with good systems for record-keeping were used in order to estimate dementia-specific mortality in all of the 191 other countries and territories. In low-income countries where fewer data were available, estimates from high-income countries cannot necessarily be applied. In addition, case ascertainment varies significantly even within each country, adding uncertainty to the assumptions underlying the models used. Overall, the current data are not robust enough to inform policy makers, researchers, and clinicians about global differences in dementia trends, clusters of dementia, and causal risk factors.

The value of the report, ${ }^{1}$ however, should not be understated, as it is probably the best estimation of the severity of the global dementia burden to date. Due to the limitations mentioned above, additional national and regional data need to be added to the model, as the intended use of the report for national policy-making may be of limited value.

The authors and others ${ }^{1,3}$ point to the importance of identifying causal risk factors in the population that can trigger interventions to prevent or delay dementia. In the current study, 4 risk factors contributed to $22 \%$ of disability-adjusted life-years. ${ }^{1}$ The distribution of these risk factors and other risk factors currently not considered in this report may vary greatly between cultures and socioeconomic conditions, which may or may not transpose to national statistics. This is exemplified by the double burden of disease in low-income and selected middle-income countries, which also has repercussions on the causes of dementia that, in those countries, are of both communicable and noncommunicable nature. A future version of this report therefore would
Correspondence

Dr. Korsnes

markor@ous-hf.no

From the Department of Old Age Psychiatry, Oslo University Hospital, Department of Psychology (M.S.K.), and Centre for Global Health, Institute of Health and Society (A.S.W.), University of Oslo, Norway; and Global Neurology Group and Center for Global Health, Department of Neurology (A.S.W.), Technical University of Munich, Germany.

Go to Neurology.org/N for full disclosures. Funding information and disclosures deemed relevant by the authors, if any, are provided at the end of the article. 
benefit from more active national involvement and calibration using in-depth analysis and systematization of existing or gathering of new national data. Although record-keeping varies and quality improving feedback on cause of death, prevalence, and disability-adjusted life-years may be inadequate in several countries, the report needs more local consideration to increase its credibility. A future global approach may also find inspiration in the Lancet Neurology Commission on Alzheimer's disease and related dementias of aging, which included genetic studies in addition to epidemiologic studies, in an attempt to map the challenges in dementia prevention and care at a European level. ${ }^{2}$

Although investigation into the different causes of dementia is important in terms of locally adapted disease prevention, culturally sensitive management of individuals who already have dementia seems equally relevant and not only refers to patients but also to their families and caregivers. Little is known about the effect of cultural differences on care for the elderly, but it may be assumed that quality of life in patients with dementia varies irrespective of the socioeconomic status of a country. ${ }^{4}$ Where dementia is misunderstood, it causes preventable suffering for families burdened with informal care and for patients with dementia. ${ }^{5}$ Dementia care in family and community-based cultures may provide important lessons that may be of value in more institution-based cultures and clearly points to the importance of a multidisciplinary approach, not only including biomedical aspects but also a social science perspective. Local and cultural particularities, benefits, and risk factors are not considered in the current report; however, the necessity for national calibration seems to be the most important future focus and will require national teams to conduct synchronous work throughout the world.

\section{Study funding}

No targeted funding reported.

\section{Disclosure}

M.S. Korsnes and A.S. Winkler report no relevant disclosures. Go to Neurology.org/N for full disclosures.

\begin{tabular}{lll}
\multicolumn{2}{l}{ Appendix } & Authors \\
\hline Name & Location & Contribution \\
\hline $\begin{array}{l}\text { Maria } \\
\text { Stylianou } \\
\text { Korsnes }\end{array}$ & $\begin{array}{l}\text { Oslo University Hospital, } \\
\text { University of Oslo, Norway }\end{array}$ & $\begin{array}{l}\text { Drafted the manuscript } \\
\text { for intellectual content }\end{array}$ \\
\hline $\begin{array}{l}\text { Andrea } \\
\text { Sylvia } \\
\text { Winkler }\end{array}$ & Technical University of & $\begin{array}{l}\text { Drafting and revision } \\
\text { for intellectual content }\end{array}$ \\
\hline
\end{tabular}

\section{References}

1. GBD 2016 Dementia Collaborators. Global, regional, and national burden of Alzheimer's disease and other dementias, 1990-2016: a systematic analysis for the Global Burden of Disease Study 2016. Lancet Neurol 2019;18:88-106.

2. Winblad B, Amouyel P, Andrieu S, et al. Defeating Alzheimer's disease and other dementias: a priority for European science and society. Lancet Neurol 2016;15:455-532.

3. Launer LJ. Statistics on the burden of dementia: need for stronger data. Lancet Neurol 2018;18:25-27.

4. Niedzwiedz CL, Katikireddi SV, Pell JP, Mitchell R. Life course socio-economic position and quality of life in adulthood: a systematic review of life course models. BMC Public Health 2012;12:628.

5. Walker R, Paddick SM. Dementia prevention in low-income and middle-income countries: a cautious step forward. Available at: thelancet.com/journals/langlo/article/PIIS2214-109X(19)30169-X/fulltext. Accessed April 25, 2019.

\section{Disputes \& Debates: Rapid online correspondence}

The editors encourage comments on recent articles through Disputes \& Debates:

Access an article at Neurology.org/N and click on "MAKE COMMENT" beneath the article header. Responses will be posted as rapidly as possible.

Before submitting a comment to Disputes \& Debates, remember the following:

- Disputes \& Debates is restricted to comments about articles published in Neurology within the last 8 weeks

- Read previously posted comments; redundant comments will not be posted

- Your submission must be 200 words or less and have a maximum of 5 references; the first reference must be the article on which you are commenting

- You can include a maximum of 5 authors (including yourself) 


\section{Neurology}

\section{Global, regional, and national burden of dementia, 1990-2016: Predictions need local calibration}

Maria Stylianou Korsnes and Andrea Sylvia Winkler

Neurology 2020;94;718-719 Published Online before print April 3, 2020

DOI 10.1212/WNL.0000000000009301

\section{This information is current as of April 3, 2020}

\section{Updated Information \& Services}

References

Subspecialty Collections

Permissions \& Licensing

Reprints including high resolution figures, can be found at: http://n.neurology.org/content/94/16/718.full

This article cites 4 articles, 0 of which you can access for free at: http://n.neurology.org/content/94/16/718.full\#ref-list-1

This article, along with others on similar topics, appears in the following collection(s):

All Cognitive Disorders/Dementia

http://n.neurology.org/cgi/collection/all_cognitive_disorders_dementia Burden of disease

http://n.neurology.org/cgi/collection/burden_of_disease

Health policy

http://n.neurology.org/cgi/collection/health_policy

Health systems

http://n.neurology.org/cgi/collection/health_systems

Public health

http://n.neurology.org/cgi/collection/public_health

Information about reproducing this article in parts (figures,tables) or in its entirety can be found online at:

http://www.neurology.org/about/about_the_journal\#permissions

Information about ordering reprints can be found online:

http://n.neurology.org/subscribers/advertise

Neurology ${ }^{\circledR}$ is the official journal of the American Academy of Neurology. Published continuously since 1951, it is now a weekly with 48 issues per year. Copyright @ 2020 American Academy of Neurology. All rights reserved. Print ISSN: 0028-3878. Online ISSN: 1526-632X.

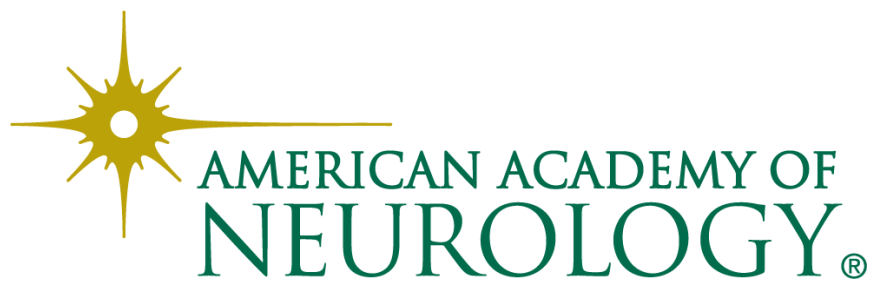

